\title{
Chemoselective Copper-Mediated Radical Modification of Selenocysteines in Peptides and Proteins
}

\author{
Zhenguang Zhao ${ }^{1}$ and Norman Metanis ${ }^{1, *}$ \\ 1. The Institute of Chemistry, The Hebrew University of Jerusalem, Edmond J. Safra \\ Campus, Givat Ram, Jerusalem 91904, Israel
}

Corresponding should be addressed to: Metanis@mail.huji.ac.il

\begin{abstract}
Highly valuable bioconjugated molecules must be synthesized through efficient, chemoselective chemical modifications of peptides and proteins. Herein we report the chemoselective modification of peptides and proteins via a reaction between selenocysteine residues and aryl/alkyl radicals. In situ radical generation from hydrazine substrates and copper ions proceeds rapidly in neat aqueous buffer at near neutral $\mathrm{pH}(5-8)$, providing a variety of Semodified linear and cyclic peptides and proteins conjugated to aryl and alkyl molecules, as well as to affinity label tag (biotin). This chemistry opens a new avenue for chemical protein modifications.
\end{abstract}

Protein post-translational modifications (PTMs) play a prominent role in expanding proteins function and enable the precise modification of proteins with a diverse range of functional moieties. ${ }^{1}$ While PTMs are normally facilitated by enzymatic processes, chemists have turned their attention on the development of regio- and chemoselective chemical modifications of proteins based on metal or organic catalysis. In recent years we have witnessed significant progress in the field, as many research groups have contributed to a rich chemical toolbox with precise and highly chemoselective reactions, ${ }^{2}$ most of which work in aqueous solutions and under ambient conditions..$^{3-7}$ Among the 20 canonical amino acids, cysteine (Cys) is still the most extensively targeted for chemical modifications, owing to its high nucleophilicity and low abundance (1.7\% of known sequences) ${ }^{8-12}$ This includes classical thiol-ene chemistry, ${ }^{13}$ typical nucleophilic substitution reactions with electrophiles ${ }^{8-10,14-15}$ or transition metal-mediated modifications. ${ }^{16-19}$ Because these reactions require a free Cys residue, site-selectivity among multiple free Cys residues in the protein sequence has eluded protein chemists (Fig. 1a). ${ }^{20}$ Therefore, it is important to develop complementary protein modification methods based on other amino acid residues that are chemoselective even in the presence of Cys residues.

Selenocysteine (Sec, $\mathrm{U}$ ), the $21^{\text {st }}$ natural amino acid, ${ }^{21}$ is Cys's isostere and shares many of its properties, with notable differences including lower $\mathrm{p} K_{\mathrm{a}}^{22,23}$ and reduction potential. ${ }^{24-26}$ These differences have been explored in chemical protein synthesis, ${ }^{27-29}$ modification, ${ }^{30-31}$ and folding. ${ }^{32-39}$ Similar to Cys, Sec's inherent nucleophilicity makes it a good target for chemical modification in peptides and proteins. ${ }^{9,11,15,40-41}$ Meanwhile, Sec is readily oxidized to diselenide (Se-Se) or selenylsulfide (Se-S), hence a reducing reagent, such as DTT or tris(2carboxyethyl)phosphine (TCEP), is typically needed to generate free selenol in aerobic conditions (Fig. 1a). However, both reagents reduce disulfide crosslinks as well, and TCEP is known to cause undesired deselenization. ${ }^{27}$ Both outcomes would interfere with the intended 
modification reactions. Recently, Buchwald and Pentelute exploited the electrophilicity of oxidized Sec, and, using arylboronic acids with either copper catalysts or electron-rich aromatic conjugates, showed regio- and chemoselective modification of oxidized Sec in peptides and proteins (Fig. 1b). ${ }^{42,43}$

Here, we report a previously unexplored, chemoselective Sec-modification with a series of hydrazine compounds in the presence of copper ions. This strategy exploits the efficient generation of alkyl/aryl radical from hydrazine substrates in the presence of $\mathrm{Cu}(\mathrm{II}),{ }^{44-47}$ which readily reacts with $\mathrm{Sec}$ in peptides and proteins to provide the desired corresponding conjugates (Fig. 1c).

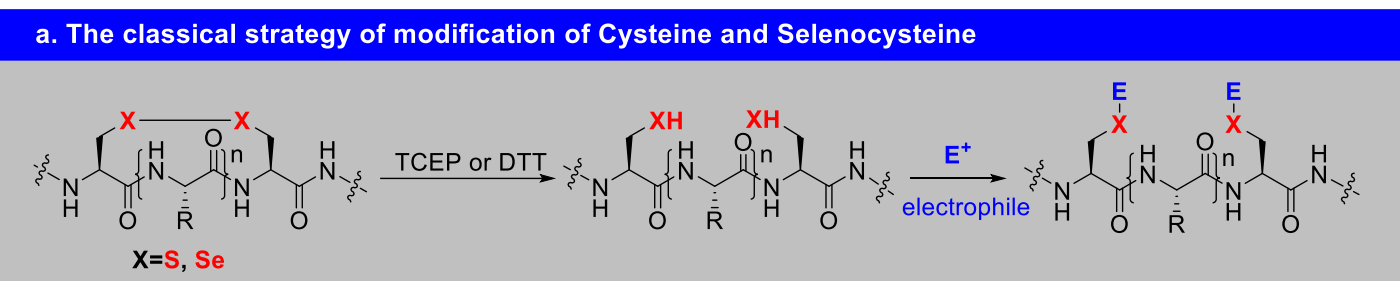

\section{b. Umpolung Modification of Selenocysteine (References 42-43)}

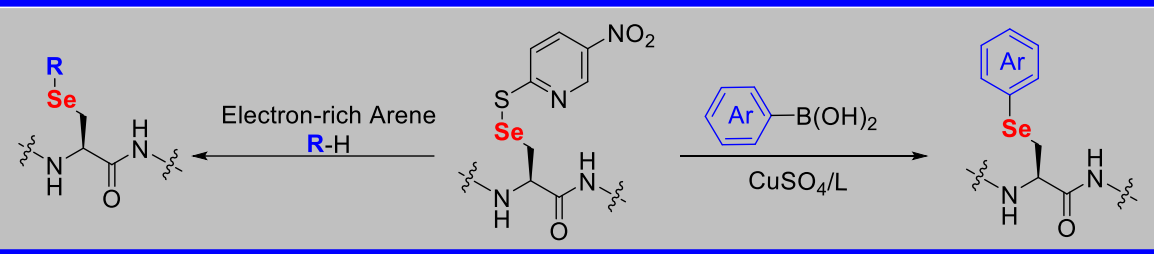

c. Selective Radical Modification of Selenocysteine (This work)

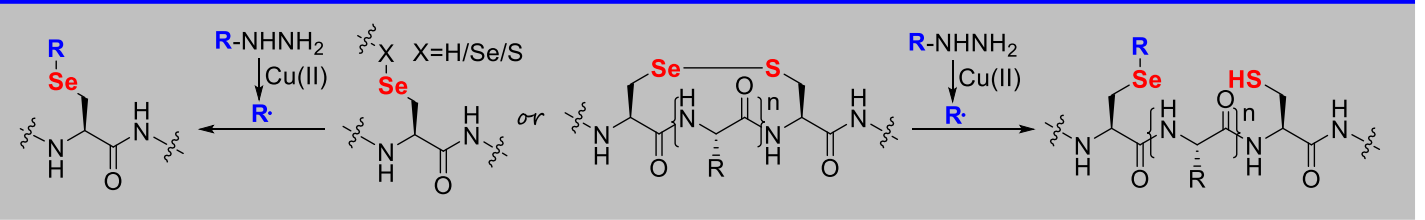

Figure 1. Modification of Sec/Cys in peptides and proteins

Recently, we reported on the use of $\mathrm{Cu}$ (II) ions for the deprotection of selenazolidine (Sez) and thiazolidine (Thz) during chemical protein synthesis, ${ }^{48-50}$ and proposed that $\mathrm{Cu}$ (II) acts as a Lewis acid that binds the selenium of Sec. In addition, Arsenyan's group reported the use of $\mathrm{Cu}$ (II) in binding the Se atom of $\mathrm{Ph}_{2} \mathrm{Se}_{2}$, which was followed by oxidation to electrophilic $\mathrm{PhSe}^{+}$, which in turn reacted with triple-bond-containing molecules. ${ }^{51}$ Almost half a century ago, it was reported that $\mathrm{Cu}(\mathrm{II})$ (and other metal ions) can oxidize phenylhydrazine to generate a phenyl radical, which can react with biomolecules in vivo. ${ }^{44,52-53}$ Of note, the deselenization reaction of $\mathrm{Sec}$ to $\mathrm{Ala}^{27-28}$ (and Ser) ${ }^{28,54}$ in the presence of TCEP was proposed to go through a radical mechanism, owing to the ability of Se atoms to form radicals under mild conditions. Hence, we envisioned that the hydrazine reagents with $\mathrm{Cu}(\mathrm{II})$ could provide an efficient approach for chemoselective modification of Sec residues in peptides and proteins through a radical reaction (Fig. 1c, and Fig. S1 in the Supporting Information, SI).

To test our hypothesis, a Sec-containing model peptide, TFUGK-NH $\mathbf{N H}_{2}$ dimer (1a), was prepared by standard Fmoc-SPPS, and 3,5-dimethylphenylhydrazine (2a) was employed as model substrate. Combining model peptide (1a, $1.0 \mathrm{mM}$ for the selenol monomer) with $2 \mathrm{mM}$ of $\mathbf{2 a}$ 
and 0.5 equiv $\mathrm{CuSO}_{4} \cdot 5 \mathrm{H}_{2} \mathrm{O}$ in phosphate buffer $(10 \mathrm{mM}, \mathrm{pH}$ 6) provided the desired product 3a in $70 \%$ yield in $10 \mathrm{~min}$ (Table 1, entry 1) at room temperature. The yield increased to $95 \%$ with 1.0 equiv $\mathrm{CuSO}_{4} \cdot 5 \mathrm{H}_{2} \mathrm{O}$ (entry 2 ) but was not improved further with more $\mathrm{Cu}(\mathrm{II}$ ) (entry 2 , Fig. S3). Expectedly, the yield of $\mathbf{3 a}$ decreased to $60 \%$ (entry 4 ) and $80 \%$ (entry 5 ) when the concentration of hydrazine $\mathbf{2 a}$ was decreased to 1.2 and $1.5 \mathrm{mM}$, respectively (Fig. S4). Varying $\mathrm{pH}$ conditions (entries 2, 6-10, Fig. S5) showed that slightly acidic conditions ( $\mathrm{pH}$ 6, entry 2) gave optimized yield of $\mathbf{3 a}$.

Table 1. Optimization of the reaction conditions.

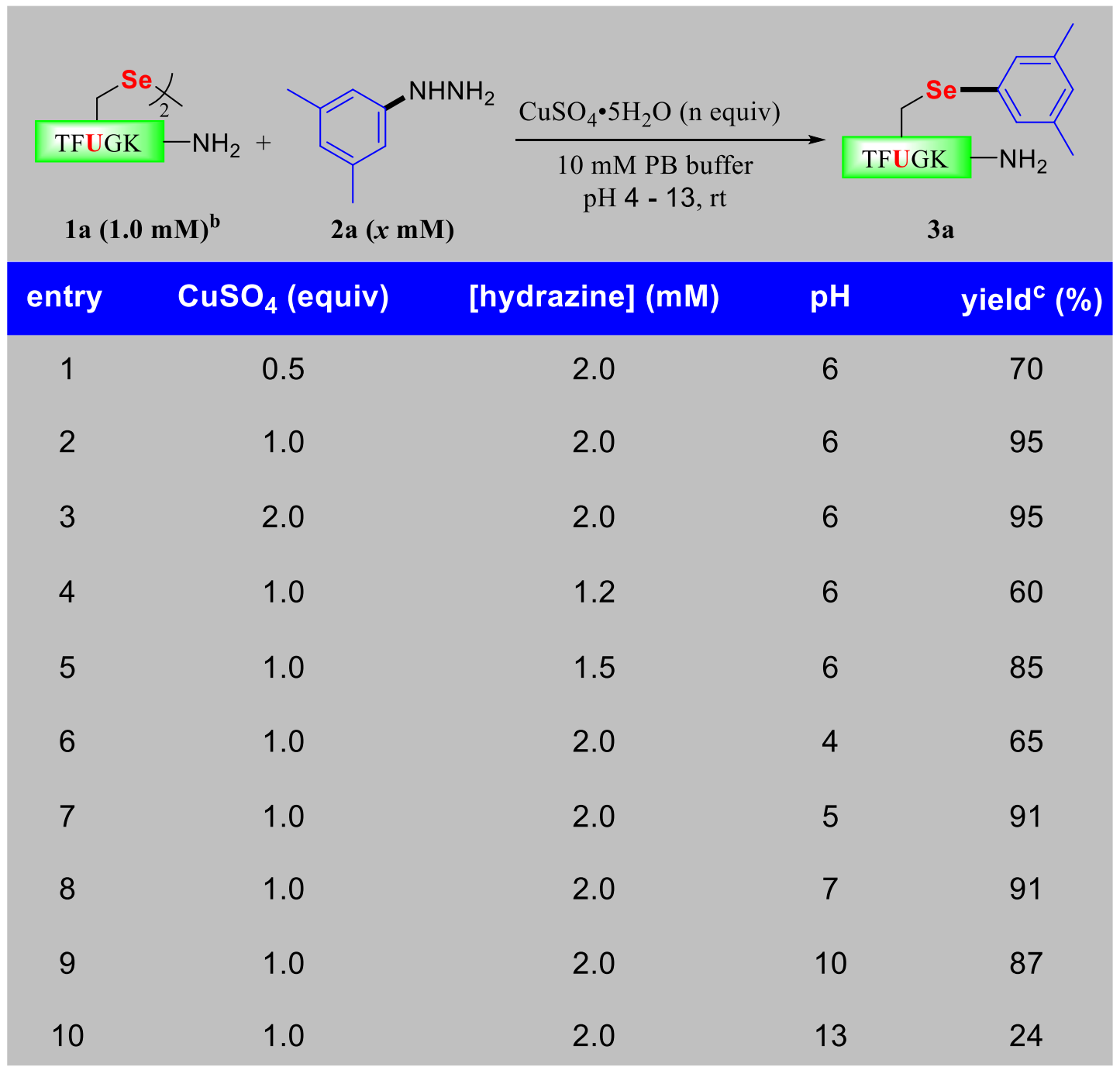

${ }^{a}$ Further details can be found in Supporting Information. ${ }^{b} 1.0 \mathrm{mM}$ of reduced peptide. ${ }^{c}$ Yields calculated according to integrated areas of HPLC peaks.

With the optimized reaction conditions in hand, we next investigated the scope of hydrazine derivatives tolerated in the modification reaction. As shown in Fig. 2, we tested the reaction between the model peptide 1a and aromatic hydrazine substrates with electron-donating groups on the phenyl ring, such as 3,5-dimethyl (2a) and p-methoxyl (2b) substituents (Fig. 2a). Both reactions were completed within 10 minutes and generated the corresponding products with excellent yields (3a and 3b, Fig. S5, S6). Unsubstituted phenylhydrazine (2c) reacted with 
model peptide 1a to form the modified product (3c) with $95 \%$ conversion (Fig. S7), implying that the electron-donating groups on the phenyl ring are not required for the modification of Sec residue in peptides. Furthermore, 4-hydrazineylbenzoic acid (2d), which contained a weak electron-withdrawing group ( $p$-carboxyl), was also found to be effective under the optimized conditions (Fig. S8). However, when the extremely electron-poor perfluorophenylhydrazine (2e) was used as a substrate, the strong electron-withdrawing substituents slowed down the reaction and only $19 \%$ conversion of modified product (3e) was observed after prolonged incubation (3 h, Fig. S9). As a heteroarene, 4-hydrazineylpyridine (2f) was also tolerated in this reaction system and afforded the desired product (3f) in good yield within $3 \mathrm{~h}$ (Fig. 2b, and Fig. S10). Given that the diversity of substrates is one of the most challenging targets in in vitro peptide modification, we decided to test the applicability of alkyl hydrazine substrates, which are less reactive than aromatic hydrazine due to the unstable radical intermediates, ${ }^{55}$ in this reaction. We were delighted to find that all tested hydrazines including benzyl, isobutyl, isopropyl and tert-butyl hydrazines proceeded smoothly to form the modified products in moderate-to-good yields (52-93\%, 3g-3j) and within 1-3 h (Fig. 2c, and Fig. S11-S14). Notably, the reaction of the model peptide $\mathbf{1 a}$ with isobutylhydrazine (2h) provided the isobutyl modified product $\mathbf{3 h}$, while the reaction with tert-butylhydrazine ( $\mathbf{2} \mathbf{j})$ provided the tert-butyl product $\mathbf{3} \mathbf{j}$. This was supported by HPLC data (Fig. S53) and unequivocally confirmed with NMR analysis (Fig. S12, $\mathrm{S} 14$ ) of the two products, $\mathbf{3} \mathbf{h}$ and $\mathbf{3} \mathbf{j}$, suggesting that the reaction was so rapid that any undesired 1,2-rearrangement of isobutyl radical, which could occur to generate stabilized tert-butyl radical, ${ }^{56}$ had not taken place. Furthermore, (cyclopropylmethyl)hydrazine (2k, Fig. 2d) reacted with the model peptide 1a to afford the exclusive cyclopropane-opened modified product $\mathbf{3 k}$ (Fig. S15), which supports the formation of radical intermediates in this transformation. ${ }^{57}$ Lastly, the biotin affinity tag (31, see scheme S2 for synthesis details) was successfully introduced to the model peptide (1a) within 10 minutes by our developed protocol (Fig. 2e, and Fig. S16). 
The modification of selenocysteine in peptide with various hydrazine compounds

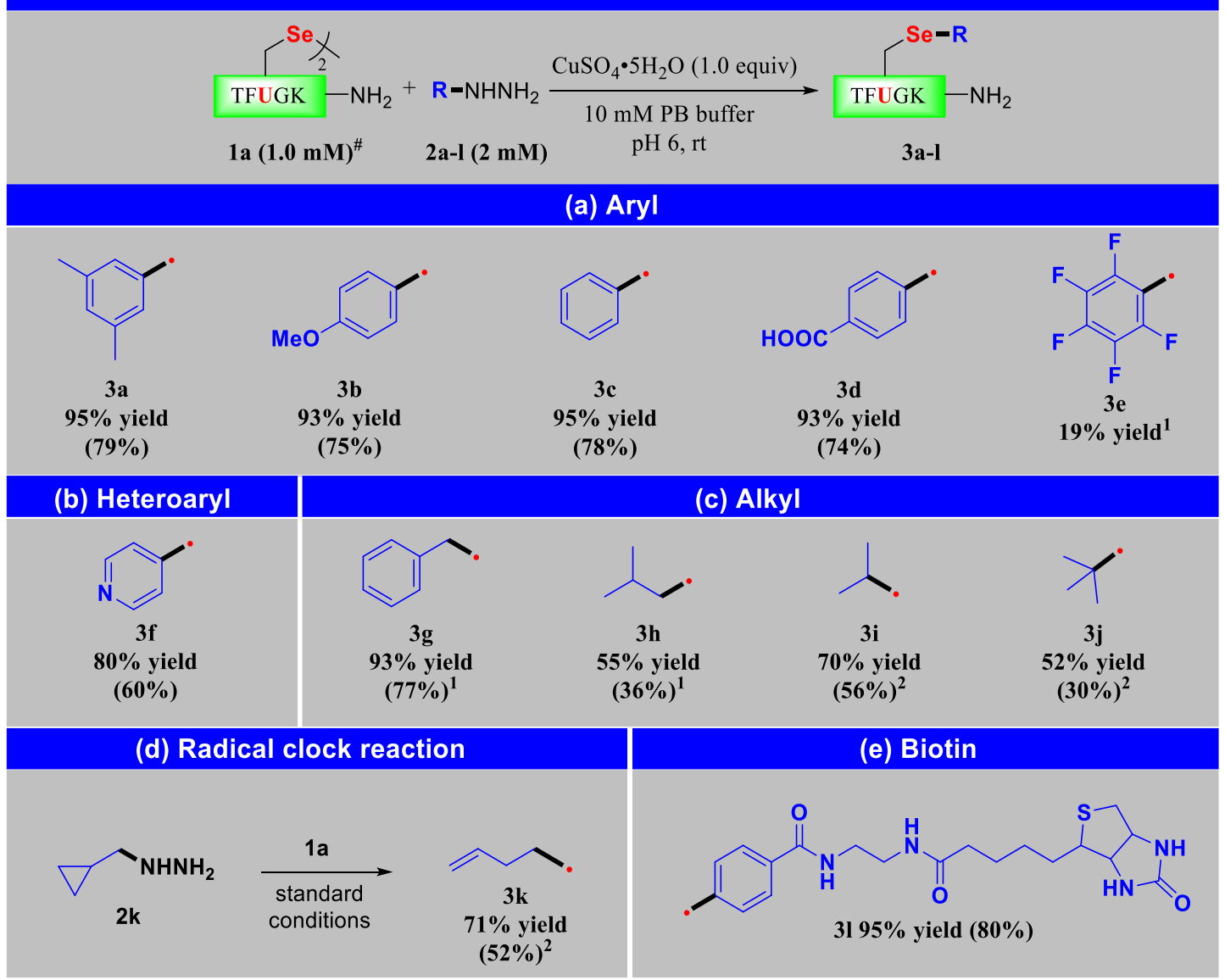

Figure 2. The substrate scope of hydrazines. ${ }^{\#} 1.0 \mathrm{mM}$ with respect to the selenol monomer. (a) The reactions for 3a-3d were performed at room temperature and the yields were obtained after $10 \mathrm{~min},{ }^{1}$ while for $\mathbf{3 e}$ was obtained after $3 \mathrm{~h}$. Yields presented were determined by HPLC analysis, while isolated yields are in parentheses. (b) The reaction performed at $37^{\circ} \mathrm{C}$ and the yield was obtained after $2 \mathrm{~h}$. (c) The reaction performed at $37^{\circ} \mathrm{C}$, ${ }^{1}$ the yields of $\mathbf{3 g}$ and $\mathbf{3 h}$ were obtained after $1 \mathrm{~h},{ }^{2}$ the yields of $\mathbf{3 i}, \mathbf{3} \mathbf{j}$ and $\mathbf{3 k}$ were obtained after $2 \mathrm{~h}$. (d) Radical clock reaction. (e) Biotinylation of the model peptide 1a under the optimized conditions.

Next, we turned to study the tolerance of this modification on unprotected amino acid sidechains. Firstly, in the absence of Sec residue, the peptide ALKFAG-NH $\mathbf{N H}_{\mathbf{2}}$ (1b) was inert to the reaction with phenylhydrazine (2c) under the optimized conditions (Fig. 3a, and Fig. S17). Due to the similar properties of sulfur and selenium, the chemoselectivity of this reaction was tested. Thus, peptide LKFCAG-NH 2 (1c) showed 10\% Cys-modified products (Fig. S18), while 13\% of Met modification product was obtained for LKMAG-NH $\mathbf{N H}_{2}$ (1d) (Fig. 3a, and Fig. S19), both of which were only observed after an extended time (2-18 h) when compared to the Sec reaction $(<10 \mathrm{~min})$.

To establish the versatility of this methodology, the modification of more complex peptide substrates (1e and 1f, Fig. 3b), which contained various functional groups, was also evaluated. When the modification of peptide $1 \mathbf{e}$ was conducted under the standard conditions, the modified product (4e) was obtained in 16\% yield. Yet, yield of product $4 \mathbf{e}$ increased to $73 \%$ yield when the concentration of phenylhydrzaine (2c) was increased to $5 \mathrm{mM}$, the amount of $\mathrm{CuSO}_{4}$ was 
increased to 2 equiv, and the reaction was incubated for $30 \mathrm{~min}$ (Fig. 3b). Note that even with excess phenylhydrazine (2c) used in this reaction, only a minor degree of arylation at the Cys residue ( $\sim 3 \%)$ was observed (Fig. S20). Moreover, trypsin digestion of $4 \mathbf{e}$ confirmed the siteselective modification of Sec residue of the peptide (Fig. S24).

The radical conjugation was similarly successful in a variety of more unusual circumstances. Because peptide 1f contains a Met residue at its N-terminus, which can be easily oxidized (Met(O)), we decided to do the reaction under argon. Hence, $\mathrm{Cu}(\mathrm{II})$ was provided in excess, to compensate for the absence of molecular oxygen (usually required for the hydrazine oxidation step, see Scheme $\mathrm{S} 1$ in $\mathrm{SI}$ ). Therefore, using 8 equiv $\mathrm{CuSO}_{4}$, peptide 1 f reacted with phenylhydrazine (2c) to afford the corresponding monoarylated product (4f) in 95\% yield (Fig. 3b, and Fig. S21), with no side-reactions observed on other functional groups in the peptide. Furthermore, the modification of head-to-tail cyclic peptide $1 \mathrm{~g}$ proceeded smoothly to form the product $(\mathbf{4 g})$ in $88 \%$ yield (Fig. 3c, and Fig. S22), which further demonstrates the potential of this transformation in the late-stage modification of biomolecules. Finally, peptide $\mathbf{1 h}$, which possessed a selenylsulfide between selenocysteine and 2-thiol-5-nitropyridine (TNP), reacted readily with phenylhydrazine (2c), giving $96 \%$ yield of Sec-modified peptide (4h, which has the same structure as 3c) within 10 min under our standard conditions (Fig. 3d, and Fig. S23). 


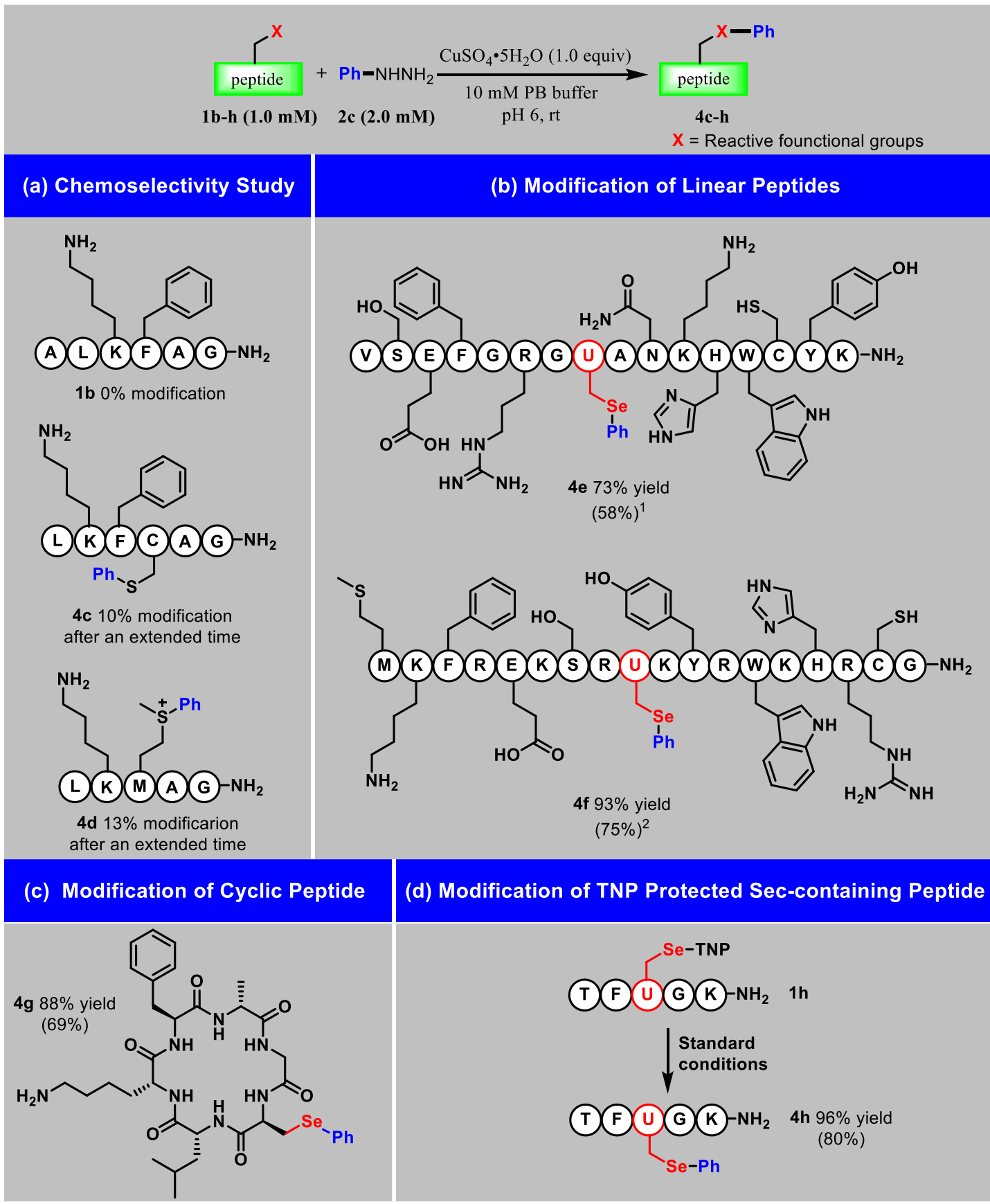

Figure 3. Systematic investigation of Sec-specific modification in the presence of other reactive

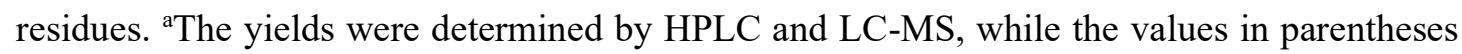
were the isolated yields. (a) Chemoselectivity study. (b) Modification of linear peptides. ${ }^{12} \mathrm{mM}$ $\mathrm{CuSO}_{4}$ and $5 \mathrm{mM}$ phenylhydrazine were used. ${ }^{2} 8 \mathrm{mM} \mathrm{CuSO}_{4}$ and $1.5 \mathrm{mM}$ phenylhydrazine, under Ar atmosphere. (c) Modification of cyclic peptide: $0.5 \mathrm{mM}$ peptide dimer (1g), $1.0 \mathrm{mM}$ with respect to the selenol monomer. (d) Modification of TNP-Sec-containing peptide, the structure of $\mathbf{4 h}$ is the same as $\mathbf{3 c}$.

With an efficient intermolecular peptide modification method established, we envisioned applying this technique to provide a cyclic peptide through the construction of an intramolecular Se-phenyl linkage (Fig. 4a). To this end, we further optimized conditions for 
peptide cyclization with a linear Sec-containing peptide (1i) bearing phenylhydrazine at the $\mathrm{N}$ terminus (Fig. S25). The cyclization of peptide 1i $(1 \mathrm{mM})$ under the standard conditions described above (10 mM PB buffer, $1 \mathrm{mM} \mathrm{CuSO}_{4}, \mathrm{pH}$ 6), provided the desired cyclic product (4i) in $45 \%$ yield after 10 minutes. Two side-products were observed (assigned as * and \# the chromatogram in Fig. 4b and Fig. S26) formed by hydrogen transfer to phenyl radical intermediate and self-coupling of phenyl radical intermediate (to give the diphenyl dimer peptide, Fig. S26), respectively. Increased yield of the desired cyclization product could be obtained when diluted peptide solutions were used. ${ }^{58-59}$ Ultimately, this transformation was further improved to obtain $74 \%$ yield of $4 \mathbf{i}$ within 10 minutes by using $50 \mu \mathrm{M}$ peptide and 10 equiv $\mathrm{CuSO}_{4}$ at slightly more acidic conditions ( $\mathrm{pH} 5$, Fig. S26), which decrease the percentage of the side-products.

\section{The cyclization of Sec-contained peptide}

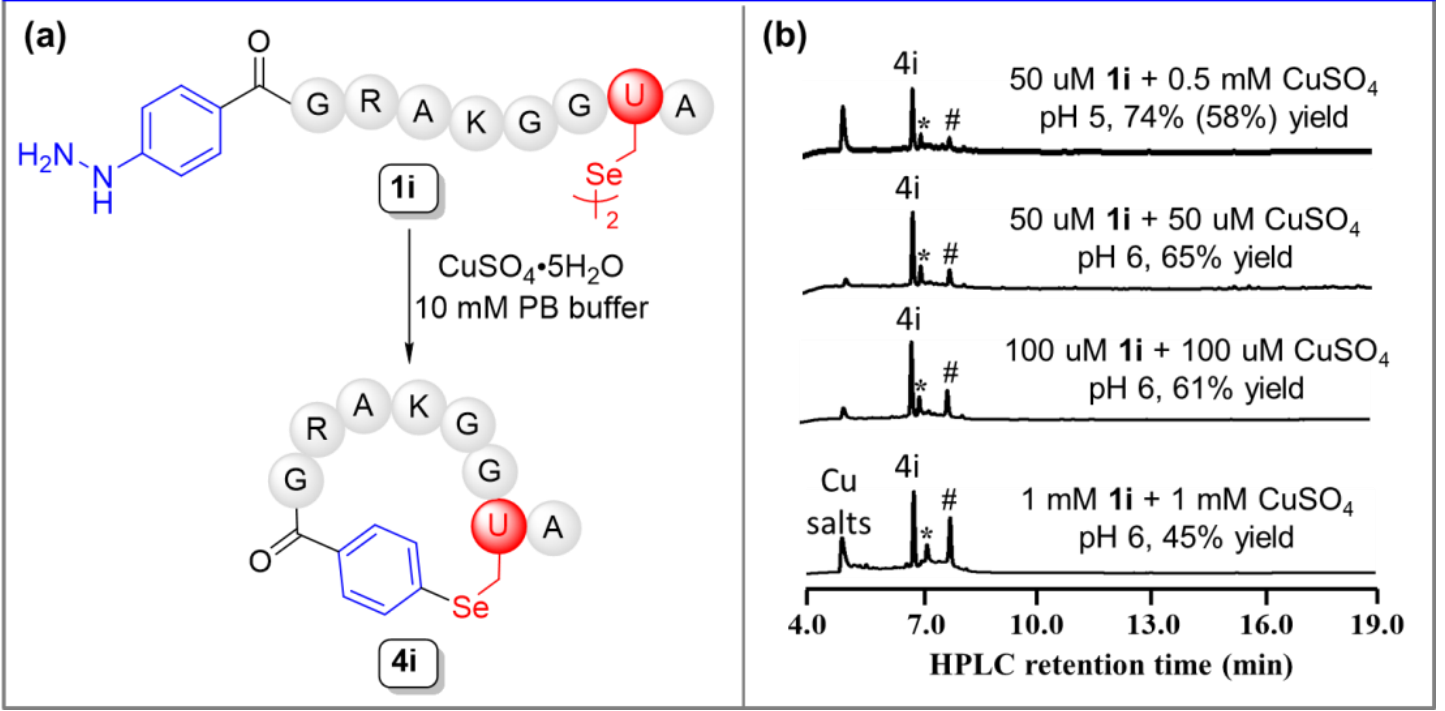

Figure 4. Intramolecular modification (a) The cyclization of Sec-contained peptide (1i) bearing phenylhydrazine at N-terminus. (b) HPLC traces of the cyclization of 1i under different conditions (room temperature, $10 \mathrm{~min}$ ). The concentrations of $\mathbf{1 i}$ are with respect to the selenol monomer. The yields were determined by HPLC and LC-MS analysis, yield in parentheses was isolated yield. * is a side-product formed by hydrogen transfer to phenyl radical intermediate, \# is a side-product formed by self-coupling of phenyl radical intermediate (Fig. S26).

Encouraged by these results, we focused on expanding our method toward a larger protein domain. The ubiquitin(G47U) variant 5a was prepared by Fmoc-SPPS ${ }^{60-62}$ and native chemical ligation (NCL) ${ }^{63}$ (Fig. S29), where the solvent-exposed Gly47 was substituted with Sec. With ubiquitin(G47U) in hand, the biotin-containing phenylhydrazine (2I) (Scheme S2) was utilized for the modification of 5a. To prevent Met oxidation in the presence of $\mathrm{Cu}(\mathrm{II})$ and $\mathrm{O}_{2},{ }^{64-65}$ the reaction of 5a was carried out under argon atmosphere. Gratifyingly, almost quantitative biotinylation of protein $\mathbf{5 a}$ was observed at $100 \mu \mathrm{M}$ concentration within $30 \mathrm{~min}$ in the presence of 4 equiv $\mathrm{CuSO}_{4}$ (Fig. 5, and Fig. S31) and the modified product 6a was isolated in 60\% yield by semi-prep HPLC. In contrast, the G47A variant of ubiquitin (5b), which was prepared by the deselenization of $\mathbf{5 a},{ }^{27-28}$ was inert to the reaction with $\mathbf{2 l}$ (see Fig. S32 for the details). 


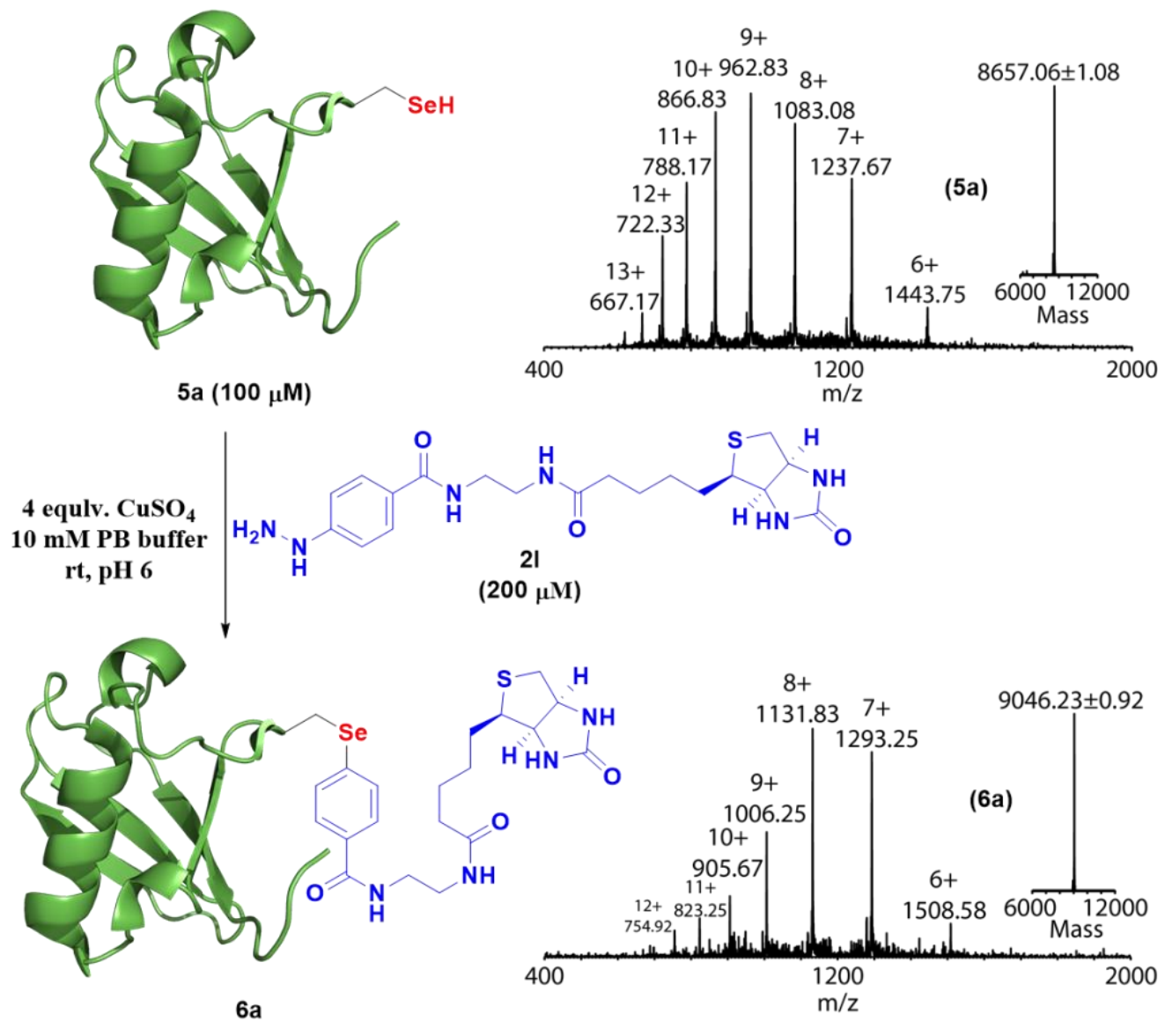

Figure 5. The modification of ubiquitin(G47U) 5a with 21, and the mass spectra of $\mathbf{5 a}$ and modified product 6a (see Fig. S60 and S61 for HR-MS data).

In summary, we have developed a general protocol for chemoselective modification of peptides and proteins via radical-mediated arylation and alkylation of selenocysteine using $\mathrm{Cu}(\mathrm{II})$ and a corresponding hydrazine. The reported facile transformation can be carried out without any reducing agent, at a near-neutral $\mathrm{pH}$ (5-8), in aqueous solution, without organic cosolvents, and under mild reaction conditions. This reaction displays a broad scope of hydrazine substrates including aromatic, heteroaryl and even alkyl hydrazines, and is highly selective, even in the presence of other reactive amino acids. In addition, oxidized and reduced selenocysteine both perform well in this transformation, which greatly expands the range of application of this technique. Furthermore, we demonstrated the high efficiency of this strategy in the preparation of cyclic peptides and the modification of larger and more complex peptides and proteins (ubiquitin). Further work to explore the labeling and fine-tuning of more complex biological molecules in vivo and in vitro with this technology is ongoing in our lab.

\section{Acknowledgments}

We would like to thank Ms. Reem Mousa, Mrs. Ricki Notis Dardashti, and Dr. Ahmad Masarwa for helpful discussions and input on the manuscript. Z.Z. is grateful for a CSC fellowship. N.M. 
acknowledges financial support from the Israel Science Foundation (783/18) and ICRF Acceleration Grant.

\section{References}

1. Walsh, C. T.; Garneau-Tsodikova, S.; Gatto Jr., G. J., Protein Posttranslational Modifications: The Chemistry of Proteome Diversifications. Angew. Chem. Int. Ed. 2005, 44, 7342-7372.

2. Davis, B. G., Mimicking Posttranslational Modifications of Proteins. Science 2004, 303, $480-$ 482.

3. Prescher, J. A.; Bertozzi, C. R., Chemistry in living systems. Nat. Chem. Biol. 2005, 1, 13-21.

4. Wright, T. H.; Bower, B. J.; Chalker, J. M.; Bernardes, G. J.; Wiewiora, R.; Ng, W. L.; Raj, R.; Faulkner, S.; Vallee, M. R.; Phanumartwiwath, A.; Coleman, O. D.; Thezenas, M. L.; Khan, M.; Galan, S. R.; Lercher, L.; Schombs, M. W.; Gerstberger, S.; Palm-Espling, M. E.; Baldwin, A. J.; Kessler, B. M.; Claridge, T. D.; Mohammed, S.; Davis, B. G., Posttranslational mutagenesis: A chemical strategy for exploring protein side-chain diversity. Science 2016, 354, agg1465.

5. Yang, A.; Ha, S.; Ahn, J.; Kim, R.; Kim, S.; Lee, Y.; Kim, J.; Söll, D.; Lee, H.-Y.; Park, H.-S., A chemical biology route to site-specific authentic protein modifications. Science 2016, 354, $623-$ 626.

6. Spicer, C. D.; Davis, B. G., Selective chemical protein modification. Nat. Commun. 2014, 5 , 4740 .

7. Kundu, R.; Ball, Z. T., Rhodium-catalyzed cysteine modification with diazo reagents. Chem. Commun. 2013, 49, 4166-4168.

8. Chalker, J. M.; Bernardes, G. J. L.; Lin, Y. A.; Davis, B. G., Chemical Modification of Proteins at Cysteine: Opportunities in Chemistry and Biology. Chem. - Asian J. 2009, 4, 630-640.

9. Embaby, A. M.; Schoffelen, S.; Kofoed, C.; Meldal, M.; Diness, F., Rational Tuning of Fluorobenzene Probes for Cysteine-Selective Protein Modification. Angew. Chem. Int. Ed. 2018, 57, 8022-8026.

10. Kasper, M. A.; Glanz, M.; Stengl, A.; Penkert, M.; Klenk, S.; Sauer, T.; Schumacher, D.; Helma, J.; Krause, E.; Cardoso, M. C.; Leonhardt, H.; Hackenberger, C. P. R., Cysteine-Selective Phosphonamidate Electrophiles for Modular Protein Bioconjugations. Angew. Chem. Int. Ed. 2019, 58, 11625-11630.

11. Cal, P. M. S. D.; Bernardes, G. J. L.; Gois, P. M. P., Cysteine-Selective Reactions for Antibody Conjugation. Angew. Chem. Int. Ed. 2014, 53, 10585-10587.

12. Gunnoo, S. B.; Madder, A., Chemical Protein Modification through Cysteine. Chembiochem 2016, 17, 529-553.

13. Hoyle, C. E.; Bowman, C. N., Thiol-Ene Click Chemistry. Angew. Chem. Int. Ed. 2010, 49, 1540 1573.

14. Zhang, Y.; Zhou, X.; Xie, Y.; Greenberg, M. M.; Xi, Z.; Zhou, C., Thiol Specific and Tracelessly Removable Bioconjugation via Michael Addition to 5-Methylene Pyrrolones. J. Am. Chem. Soc. 2017, 139, 6146-6151.

15. Spokoyny, A. M.; Zou, Y.; Ling, J. J.; Yu, H.; Lin, Y.-S.; Pentelute, B. L., A Perfluoroaryl-Cysteine SNAr Chemistry Approach to Unprotected Peptide Stapling. J. Am. Chem. Soc. 2013, 135, $5946-$ 5949 . 
16. Deng, J. R.; Chung, S. F.; Leung, A. S. L.; Yip, W. M.; Yang, B.; Choi, M. C.; Cui, J. F.; Kung, K. K. Y.; Zhang, Z.; Lo, K. W.; Leung, Y. C.; Wong, M. K., Chemoselective and photocleavable cysteine modification of peptides and proteins using isoxazoliniums. Commun. Chem. 2019, 2, 93.

17. Vinogradova, E. V.; Zhang, C.; Spokoyny, A. M.; Pentelute, B. L.; Buchwald, S. L., Organometallic palladium reagents for cysteine bioconjugation. Nature 2015, 526, 687-691.

18. Messina, M. S.; Stauber, J. M.; Waddington, M. A.; Rheingold, A. L.; Maynard, H. D.; Spokoyny, A. M., Organometallic Gold(III) Reagents for Cysteine Arylation. J. Am. Chem. Soc. 2018, 140, 7065 7069 .

19. Lu, X.; He, S.-J.; Cheng, W.-M.; Shi, J., Transition-metal-catalyzed C H functionalization for late-stage modification of peptides and proteins. Chin. Chem. Lett. 2018, 29, 1001-1008.

20. Kuan, S. L.; Wang, T.; Weil, T., Site-Selective Disulfide Modification of Proteins: Expanding Diversity beyond the Proteome. Chem. - Eur. J. 2016, 22, 17112-17129.

21. Stadtman, T. C., Selenocysteine. Annu. Rev. Biochem. 1996, 65, 83-100.

22. Byun, B. J.; Kang, Y. K., Conformational preferences and pKa value of selenocysteine residue. Biopolymers 2011, 95, 345-353.

23. Huber, R. E.; Criddle, R. S., Comparison of the chemical properties of selenocysteine and selenocystine with their sulfur analogs. Arch. Biochem. Biophys. 1967, 122, 164-173.

24. Nauser, T.; Dockheer, S.; Kissner, R.; Koppenol, W. H., Catalysis of Electron Transfer by Selenocysteine. Biochemistry 2006, 45, 6038-6043.

25. Besse, D.; Siedler, F.; Diercks, T.; Kessler, H.; Moroder, L., The Redox Potential of Selenocystine in Unconstrained Cyclic Peptides. Angew. Chem. Int. Ed. 1997, 36, 883-885.

26. Metanis, N.; Keinan, E.; Dawson, P. E., Synthetic seleno-glutaredoxin 3 analogues are highly reducing oxidoreductases with enhanced catalytic efficiency. J. Am. Chem. Soc. 2006, 128, 1668416691.

27. Metanis, N.; Keinan, E.; Dawson, P. E., Traceless ligation of cysteine peptides using selective deselenization. Angew. Chem. Int. Ed. 2010, 49, 7049-7053.

28. Dery, S.; Reddy, P. S.; Dery, L.; Mousa, R.; Dardashti, R. N.; Metanis, N., Insights into the deselenization of selenocysteine into alanine and serine. Chem. Sci. 2015, 6, 6207-6212.

29. Mitchell, N. J.; Malins, L. R.; Liu, X.; Thompson, R. E.; Chan, B.; Radom, L.; Payne, R. J., Rapid Additive-Free Selenocystine-Selenoester Peptide Ligation. J. Am. Chem. Soc. 2015, 137, 14011 14014.

30. Liu, J.; Chen, Q.; Rozovsky, S., Utilizing Selenocysteine for Expressed Protein Ligation and Bioconjugations. J. Am. Chem. Soc. 2017, 139, 3430-3437.

31. Whedon, S. D.; Markandeya, N.; Rana, A. S. J. B.; Senger, N. A.; Weller, C. E.; Tureček, F.; Strieter, E. R.; Chatterjee, C., Selenocysteine as a Latent Bioorthogonal Electrophilic Probe for Deubiquitylating Enzymes. J. Am. Chem. Soc. 2016, 138, 13774-13777.

32. Metanis, N.; Foletti, C.; Beld, J.; Hilvert, D., Selenoglutathione-Mediated Rescue of Kinetically Trapped Intermediates in Oxidative Protein Folding. Isr. J. Chem. 2011, 51, 953-959.

33. Metanis, N.; Hilvert, D., Strategic use of non-native diselenide bridges to steer oxidative protein folding. Angew. Chem. Int. Ed. 2012, 51, 5585-5588.

34. Metanis, N.; Hilvert, D., Harnessing selenocysteine reactivity for oxidative protein folding. Chem. Sci. 2015, 6, 322-325.

35. Mousa, R.; Notis Dardashti, R.; Metanis, N., Selenium and Selenocysteine in Protein Chemistry. Angew. Chem. Int. Ed. 2017, 56, 15818-15827. 
36. Weil-Ktorza, O.; Rege, N.; Lansky, S.; Shalev, D. E.; Shoham, G.; Weiss, M. A.; Metanis, N., Substitution of an Internal Disulfide Bridge with a Diselenide Enhances both Foldability and Stability of Human Insulin. Chem. - Eur. J. 2019, 25, 8513-8521.

37. Muttenthaler, M.; Nevin, S. T.; Grishin, A. A.; Ngo, S. T.; Choy, P. T.; Daly, N. L.; Hu, S.-H.; Armishaw, C. J.; Wang, C.-I. A.; Lewis, R. J.; Martin, J. L.; Noakes, P. G.; Craik, D. J.; Adams, D. J.; Alewood, P. F., Solving the $\alpha$-Conotoxin Folding Problem: Efficient Selenium-Directed On-Resin Generation of More Potent and Stable Nicotinic Acetylcholine Receptor Antagonists. J. Am. Chem. Soc. 2010, 132, 3514-3522.

38. de Araujo, A. D.; Callaghan, B.; Nevin, S. T.; Daly, N. L.; Craik, D. J.; Moretta, M.; Hopping, G.; Christie, M. J.; Adams, D. J.; Alewood, P. F., Total Synthesis of the Analgesic Conotoxin MrVIB through Selenocysteine-Assisted Folding. Angew. Chem. Int. Ed. 2011, 50, 6527-6529.

39. Gowd, K. H.; Yarotskyy, V.; Elmslie, K. S.; Skalicky, J. J.; Olivera, B. M.; Bulaj, G., Site-Specific Effects of Diselenide Bridges on the Oxidative Folding of a Cystine Knot Peptide, $\omega$ Selenoconotoxin GVIA. Biochemistry 2010, 49, 2741-2752.

40. Yu, J.; Yang, X.; Sun, Y.; Yin, Z., Highly Reactive and Tracelessly Cleavable Cysteine-Specific Modification of Proteins via 4-Substituted Cyclopentenone. Angew. Chem. Int. Ed. 2018, 57 , 11598-11602.

41. Calce, E.; De Luca, S., The Cysteine S-Alkylation Reaction as a Synthetic Method to Covalently Modify Peptide Sequences. Chem. - Eur. J. 2017, 23, 224-233.

42. Cohen, D. T.; Zhang, C.; Pentelute, B. L.; Buchwald, S. L., An Umpolung Approach for the Chemoselective Arylation of Selenocysteine in Unprotected Peptides. J. Am. Chem. Soc. 2015, 137, 9784-9787.

43. Cohen, D. T.; Zhang, C.; Fadzen, C. M.; Mijalis, A. J.; Hie, L.; Johnson, K. D.; Shriver, Z.; Plante,

O.; Miller, S. J.; Buchwald, S. L.; Pentelute, B. L., A chemoselective strategy for late-stage functionalization of complex small molecules with polypeptides and proteins. Nat. Chem. 2019, 11, 78-85.

44. Hill, H. A. O.; Thornalley, P. J., Phenyl radical production during the oxidation of phenylhydrazine and in phenylphydrazine-induced haemolysis. FEBS Lett. 1981, 125, 235-238.

45. Varea, T.; González-Núñez, M. E.; Rodrigo-Chiner, J.; Asensio, G., Aryl radicals by copper(II) oxidation of hydrazines: A new method for the oxidative and reductive arylation of alkenes. Tetrahedron Lett. 1989, 30, 4709-4712.

46. Jonnalagadda, S. B.; Nattar, K., Cu(II) catalyzed reaction between phenyl hydrazine and toluidine blue-dual role of acid. Int. J. Chem. Kinet. 1999, 31, 271-276.

47. Ren, X.; Tang, S.; Li, L.; Li, J.; Liang, H.; Li, G.; Yang, G.; Li, H.; Yuan, B., Surfactant-Type Catalyst for Aerobic Oxidative Coupling of Hydrazine with Thiol in Water. J. Org. Chem. 2019, 84, 86838690 .

48. Zhao, Z;; Metanis, N., Copper-Mediated Selenazolidine Deprotection Enables One-Pot Chemical Synthesis of Challenging Proteins. Angew. Chem. Int. Ed. 2019, 58, 14610-14614.

49. Zhao, Z.; Metanis, N., Utilizing Copper-Mediated Deprotection of Selenazolidine for Cyclic Peptide Synthesis. J. Org. Chem. 2020, 85, 1731-1739.

50. Naruse, N.; Kobayashi, D.; Ohkawachi, K.; Shigenaga, A.; Otaka, A., Copper-Mediated Deprotection of Thiazolidine and Selenazolidine Derivatives Applied to Native Chemical Ligation. J. Org. Chem. 2020, 85, 1425-1433.

51. Arsenyan, P.; Lapcinska, S.; Ivanova, A.; Vasiljeva, J., Peptide Functionalization Through the 
Generation of Selenocysteine Electrophile. Eur. J. Org. Chem. 2019, 2019, 4951-4961.

52. Misra, H. P.; Fridovich, I., The oxidation of phenylhydrazine: superoxide and mechanism. Biochemistry 1976, 15, 681-687.

53. Kibriya, G.; Mondal, S.; Hajra, A., Visible-Light-Mediated Synthesis of Unsymmetrical Diaryl Sulfides via Oxidative Coupling of Arylhydrazine with Thiol. Org. Lett. 2018, 20, 7740-7743.

54. Malins, L. R.; Mitchell, N. J.; McGowan, S.; Payne, R. J., Oxidative Deselenization of Selenocysteine: Applications for Programmed Ligation at Serine. Angew. Chem. Int. Ed. 2015, 54, 12716-12721.

55. Shirota, H.; Pal, H.; Tominaga, K.; Yoshihara, K., Ultrafast intermolecular electron transfer in coumarin-hydrazine system. Chem. Phys. 1998, 236, 355-364.

56. Kobayashi, N.; Minami, T.; Tani, A.; Nakagoshi, M.; Sugahara, T.; Takeya, K.; Ohgaki, K., Intermolecular Hydrogen Transfer in Isobutane Hydrate. Energies 2012, 5, 1705-1712.

57. Maillard, B.; Forrest, D.; Ingold, K. U., Kinetic applications of electron paramagnetic resonance spectroscopy. 27. Isomerization of cyclopropylcarbinyl to allylcarbinyl. J. Am. Chem. Soc. 1976, 98 , 7024-7026.

58. Knops, P.; Sendhoff, N.; Mekelburger, H.-B.; Vögtle, F., High dilution reactions - New synthetic applications. Top. Curr. Chem. 1992, 161, 1-36.

59. Schiller, P. W.; Nguyen, T. M.-D.; Miller, J., Synthesis of side-chain to side-chain cyclized peptide analogs on solid supports. Int. J. Peptide Protein Res. 1985, 25, 171-177.

60. Merrifield, R. B., Solid Phase Peptide Synthesis. I. The Synthesis of a Tetrapeptide. J. Am. Chem. Soc. 1963, 85, 2149-2154.

61. Carpino, L. A.; Han, G. Y., 9-Fluorenylmethoxycarbonyl function, a new base-sensitive aminoprotecting group. J. Am. Chem. Soc. 1970, 92, 5748-5749.

62. Carpino, L. A.; Han, G. Y., 9-Fluorenylmethoxycarbonyl amino-protecting group. J. Org. Chem. 1972, 37, 3404-3409.

63. Dawson, P. E.; Muir, T. W.; Clarklewis, I.; Kent, S. B. H., Synthesis of Proteins by Native Chemical Ligation. Science 1994, 266, 776-779.

64. Younan, N. D.; Nadal, R. C.; Davies, P.; Brown, D. R.; Viles, J. H., Methionine Oxidation Perturbs the Structural Core of the Prion Protein and Suggests a Generic Misfolding Pathway. J. Biol. Chem. 2012, 287, 28263-28275.

65. Barman, A.; Taves, W.; Prabhakar, R., Insights into the mechanism of methionine oxidation catalyzed by metal (Cu2+, $\mathrm{Zn} 2+$, and $\mathrm{Fe} 3+$ )—Amyloid beta $(\mathrm{A} \beta)$ peptide complexes: A computational study. J. Comput. Chem. 2009, 30, 1405-1413. 